\title{
Blasts 5-10 Percent of Bone Marrow Nucleated Cells
}

National Cancer Institute

\section{Source}

National Cancer Institute. Blasts 5-10 Percent of Bone Marrow Nucleated Cells. NCI

Thesaurus. Code C137703.

A semi-quantitative microscopic finding indicating that between 5 and 10 percent of the nucleated cells in a bone marrow sample are immature mononuclear cells. 